\title{
Herbicidal, Insecticidal and Structure-Activity Relationship Studies on Pyranopyrazole and Oxinobispyrazole Derivatives
}

\author{
Samir A.M. Abdelgaleil ${ }^{1}$, Yonis M. Badawy ${ }^{2}$
}

\begin{abstract}
Nine pyranopyrazole and oxinobispyrazole derivatives were synthesized and their structures were confirmed by spectral analysis. The inhibitory effects of prepared compounds were evaluated on germination and seedling growth of Lolium temulentum. In addition, the insecticidal activity of synthesized compounds was tested against the fourth instar larvae of Culex pipiens. The structureactivity relationships of compounds were disclosed. The results of herbicidal activity assay revealed that the prepared compounds caused significant reduction of $L$. temulentum seed germination. Compounds 4 and 7 showed the highest seed germination reduction at the tested concentrations $(0.5,1$ and $5 \mathrm{mM})$ with complete inhibition $(100 \%)$ of seed germination at $5 \mathrm{mM}$. In contrary, compounds 2 and 9 showed the weakest reduction of germination. The tested compounds also exhibited strong root growth inhibition with compound 7 being the most potent one and compound 1 being the less potent one. Similarly the tested compounds revealed pronounced inhibition of shoot growth of $\mathbf{L}$. temulentum. Compounds 4 and 7 caused the highest shoot growth reduction at the tested concentrations. The inhibition of root growth by all compounds was greater than that of shoot growth. When tested for their insecticidal activity against the fourth instar larvae of $C$. pipiens, the tested compounds showed variable toxicity. However, compounds 4,7 and 8 were the most potent toxicants toward the larvae, while compound 2 showed the lowest activity among the tested compounds. The results revealed that compounds bearing cyanide (CN) group at the position $C-5$ such as 4,7 and 8 were the most active compounds against the tested weed and insect. In addition, the presence of phenyl moiety at $\mathrm{N}-1$ significantly increased the herbicidal and insecticidal activity of compounds such as 7 and 8 compared with other compounds. Therefore, pyranopyrazole derivatives with these substitutions may be suitable for developing new pesticides.
\end{abstract}

Key words: Pyranopyrazoles, Oxinobispyrazoles, Herbicidal activity, Insecticidal activity, Lolium temulentum, Culex pipiens, Structure-activity relationship

\section{INTRODUCTION}

Pyranopyrazoles and oxinobispyrazoles are fused five-six membered rings containing nitrogen and oxygen heterocycles. They are an important category of heterocyclic compounds, which play a significant role in pharmaceutical and agricultural fields. Compounds bearing pyranopyrazole system have been found to have various biological activities, for instance antimicrobial (Mistry et al., 2012), analgesic (Kuo et al., 1984), vasodilator (Ahluwalia et al., 1997), anticancer (Zaki et al., 2004; Wang et al., 2009), anti-inflammatory (Zaki et al., 2006), molluscicidal (Abdelrazek et al., 2006 and 2007) and antifungal (Mangalagiu et al., 2001).

Lolium temulentum L., darnel, is originated in the Mediterranean and has spread widely across temperate areas wherever wheat and cereals are grown. Its spread into tropical areas of different countries is limited by prolonged high temperature and low moisture conditions (Holm et al., 1991). The seeds of $L$. temulentum have poisonous effects on man and animals when consumed in conjunction with wheat and other cereals (Ratera, 1983; Ambasta, 1994). They are remarkably similar in size and weight to the grains of wheat and other small grain crops, which make their separation difficult. When milled with wheat, it causes the flour to become grey and bitter. The poisonous compounds are considered to be two alkaloids, temulin and loline, which are present in the seed (Bor, 1960; Smith and Bernhard, 1988), and perloline in the stem (Dannhardt and Steindl, 1985). The competitive potential of $L$. temulentum has rarely been measured, but it is generally regarded as a competitive weed. Hollies (1982) revealed that grassy weeds, such as $L$. temulentum, caused yield losses of up to $17 \%$ in wheat and barley, whereas net profits were reduced by $25 \%$. Wheat infested with $L$. temulentum can have an impaired response to $\mathrm{N}$ fertilization (Farnworth and Said, 1983). Moreover, Lolium temulentum can be a host to a variety of crop pests and diseases.

Culex is an important mosquito genus containing well-known vectors of important parasites and pathogens causing disease, such as filariasis, West Nile virus and other encephalitides. Culex pipiens are vectors of West Nile virus and an important pest to humans, causing allergic responses that include local skin reaction and systemic reactions such as angioedema, and urticaria (Cheng et al., 2008). In Egypt, eleven Culex species are widespread throughout the country

\footnotetext{
${ }^{1}$ Department of Pesticide Chemistry and Technology,

Faculty of Agriculture, El-Shatby, Alexandria University,

Alexandria 21545, Egypt.

${ }^{2}$ Department of Chemistry, Faculty of Science, Al-Azhar University,

Nasr City, Cairo, Egypt

Received September 18, 2016, Accepted October 30, 2016
} 
with $C$. pipiens L., the house mosquito, being the most common (Abd El-Samie and Abd El-Baset, 2012).

There is an urgent need for developing new chemicals to protect agricultural crops and to combat human and animal disease vectors. In addition, few studies were reported in the literature on the biological activity of pyranopyrazoles and oxinobispyrazoles against agricultural and public health pests (Abdelrazek et al., 2006 and 2007; Badawy et al., 2016). Therefore, this study aims to synthesize nine pyranopyrazole and oxinobispyrazole derivatives (1-9) and evaluate their herbicidal activity against Lolium temulentum. The insecticidal activity of pyranopyrazoles was also tested against the fourth larval instar of Culex pipiens. In addition, the relationship between chemical structure and biological activity was discussed.

\section{MATERIALS AND METHODS}

\section{Test weed}

Seeds of a field biotype Lolium temulentum L. (Poaceae) were obtained from Faculty of Agriculture Farm, Alexandria, Egypt. Uniform seeds were selected for the test while undersized and damaged seeds were discarded. Germination of the seeds was tested before use and was $70 \% 12$ days after sowing.

\section{Test insect}

Culex pipiens L. (Diptera: Culicidae) used in the bioassays was maintained in an insectary at the Department of Applied Entomology (Alexandria University, Egypt) for more than decade. Adults were kept in cages $(50 \times 50 \times 50 \mathrm{~cm})$ at $27 \pm 1{ }^{\circ} \mathrm{C}, 70 \pm 5 \% \mathrm{RH}$, and a photoperiod regime of 14:10 h (light/dark). The $10 \%$ sucrose solution, soaked in cotton swab, was provided as food for adult mosquitoes. A pigeon was introduced twice per week for adult blood feeding. Larvae were reared in dechlorinated water under the same temperature and light conditions and were fed daily with baby fish food. Newly emerged fourth instar larvae were used for bioassays.

\section{Synthesis of pyranopyrazoles (1-9)}

A general protocol for synthesis of pyranopyrazoles and oxinobispyrazoles was used for preparation of compounds 1-9 (Satyajit et al., 2013). To a mixture of 4-oxo-4H-benzopyran-3-carbaldehyde (0.01 mol), 3methyl-pyrazolone, 3-methyl-1-phenylpyrazolone (0.01 mol), ammonium acetate $(0.03 \mathrm{~mol})$ or a few drops of piperidine were added. The mixture was heated at $190^{\circ} \mathrm{C}$ for $30 \mathrm{~min}$. in methanol. After cooling, the obtained solid was washed with water, dried and crystallized from ethanol to obtain 3-(3,5-Dimethyl-1,7diphenyl-4,7-dihydro-1H-pyrano[2,3-c;6,5-c']dipyrazol4-yl)-chromen-4-one (1), 3-(3, 5-Dimethyl-4, 7dihydro-1H-pyrano [2. 3-c; 6, 5-c'] dipyrazol-4-yl) chromen-4-one (2) and 3-(3,5-Dimethyl-1-phenyl-4,7dihydro-1H-pyrano[2,3-c;6,5-c']dipyrazol-4-yl)-

chromen-4-one (3). On other experiment, to a mixture of 4-oxo-4H-benzopyran-3-carbaldehyde $(0.01 \mathrm{~mol})$, pyrazolone $(0.01 \mathrm{~mol})$, malononitrile $(0.01 \mathrm{~mol}$.) or cyanoacetic acid, ethylacetoacetate, diethyl-malonate, cyanoacetamide $(0.01 \mathrm{~mol})$, ammonium acetate $(0.03 \mathrm{~mol})$ or a few drops of piperidine were added. The mixture was heated at $120^{\circ} \mathrm{C}$ for $30 \mathrm{~min}$. in methanol. After cooling, the obtained solid was washed with water, derided and crystallized from ethanol to give 3Methyl-6-oxo-4-(4-oxo-4H-chromen-3-yl)-1,6-dihydropyrano[2,3-c]pyrazole-5-carbonitrile (4), 5-Acetyl-3methyl-4-(4-oxo-4H-chromen-3-yl)pyrano[2,3-

c]pyrazol-6(1H)-one (5), Ethyl-3-methyl-6-oxo-4-(4oxo-4H-chromen-3-yl)-1,6-dihydropyrano[2,3-

c]pyrazole-5-carboxylate (6), 6-Amino-3-methyl-4-(4oxo-4H-chromen-3-yl)-1-phenyl-1, 4-dihydropyrano [2, 3-c] pyrazole-5-carbonitrile (7): 3-Methyl-6-oxo-4-(4oxo-4H-chromen-3-yl)-1-phenyl-1,6-dihydro-

pyrano[2,3-c]pyrazole-5-carbonitrile (8) and 6-Amino3-methyl-4-(4-oxo-4H-chromen-3-yl)-1-phenyl-1,4dihydro-pyrano[2,3-c]pyrazole-5-carboxamide (9). The chemical structures (Figure 1) of prepared compounds were identified based on their spectral data of IR, ${ }^{1} \mathrm{H}-$ NMR and MS (Khurana and Chaudhary, 2012; Badawy et al., 2016).

\section{Phytotoxic Bioassay}

A bioassay based on germination and subsequent seedling growth was carried out to study the phytotoxic effects of the nine pyranopyrazoles and oxinobispyrazoles on seeds of Lolium temulentum (Abdelgaleil et al., 2009) The solutions of tested pyranopyrazoles were initially prepared in dimethyl sulfoxide (DMSO) and then diluted with distilled water containing $0.02 \%$ of an emulsifying agent (Triton-X $100)$ to give the concentrations of $0.5,1$ and $5 \mathrm{mM}$. The treatments with distilled water containing DMSO $(0.5 \%$ $\mathrm{v} / \mathrm{v})$ and Triton-X $100(0.02 \%)$ were taken as the controls. The use of DMSO and Triton-X 100 at these concentrations did not reduce germination or plant growth compared to a water only control. Three replicates, each of 20 seeds, were prepared for each treatment using glass Petri dishes $(9 \mathrm{~cm})$ lined with Whatman No. 2 filter paper. Six milliliters of each concentration was added to individual Petri dishes. Afterward, Petri dishes were placed in the bottom of 0.1 $\mathrm{mm}$ thick polyethylene bags $(15$ by $30 \mathrm{~cm})$ that were expanded to contain air and then closed at the top with rubber bands to prevent the loss of moisture. The Petri dishes were placed in a growth chamber at $22 \pm 2{ }^{\circ} \mathrm{C}$ with a 12-h photoperiod. Twelve days after sowing, the germination was determined by counting the number of germinated seeds and the lengths of root and shoot were 
measured. The growth reduction percentages of root and shoot lengths were calculated from the following equation: $\mathrm{R}(\%)=[1-\mathrm{T} / \mathrm{C}] \times 100$; where $\mathrm{T}$ is the root or shoot length of treatment $(\mathrm{cm})$ and $\mathrm{C}$ is the root or shoot length of control $(\mathrm{cm})$.

\section{Insecticidal bioassay}

The larval mortality bioassay was carried out using the recommended method of the World Health Organization (WHO, 1996). Stock solutions of the tested pyranopyrazoles and oxinobispyrazoles were prepared in dimethyl sulfoxide (DMSO). Groups of 20 $C$. pipiens fourth instar larvae were separately put into 200-ml plastic cups containing $100 \mathrm{ml}$ of distilled water. The tested compounds solutions in $0.1 \mathrm{ml}$ DMSO were added to each cup and suspended with Tween-20 $(0.1 \mathrm{ml})$, with gentle shaking to ensure a homogeneous test solution. The compounds were tested at concentrations 125,250 and $500 \mathrm{mg} / \mathrm{L}$. The control was prepared with distilled water containing the same amount of DMSO and Tween-20. There were three replicates for each concentration. Treated and control larvae were held in the same conditions used for colony rearing. Larval mortalities were recorded 24 and $48 \mathrm{~h}$ post-treatment. Larvae were considered dead when they did not respond to stimulus or did not rise to the surface of the solution.

\section{Statistical analysis}

Germination percentages, root and shoot lengths, and mortality percentages were subjected to one-way analysis of variance followed by Student-NewmanKeuls test (Cohort Software Inc. 1985) to determine significant differences among mean values at the probability level of 0.05 .

\section{RESULTS AND DISCUSSION}

\section{Effect of pyranopyrazoles and oxinobispyrazoles on seed germination}

The effect of the nine pyranopyrazoles and oxinobispyrazoles (1-9) on the seed germination of $L$. temulentum 12 days after sowing is given in Table 1. The results reveal that the tested pyranopyrazoles and oxinobispyrazoles caused significant reduction of seed germination at the tested concentrations except compound 9 at concentrations 0.5 and $1 \mathrm{mM}$. At 0.5 $\mathrm{mM}$, compound 7 gave the highest reduction in seed germination, followed by 1 and 3, while 9, 5 and 2 were the less effective compounds at this concentration. Compound 7 caused the highest seed germination reduction at concentration of $1 \mathrm{mM}$ with $28.3 \%$ seed germination. In contrary, 8 had the weakest effect on seed germination at $1 \mathrm{mM}$. In the case of $5 \mathrm{mM}$, compounds 4 and 7 caused complete inhibition (100\%) of seed germination. Compounds 1,8 and 6 caused strong reduction of seed germination at this concentration with $13.3,18.3$ and $20.0 \%$ seed germination, respectively, whereas 3, 9 and 2 were the less effective compounds at this concentration.

Table 1. Effect of pyranopyrazoles and oxinobispyrazoles on Lolium temulentum seed germination 12 days after sowing ${ }^{\mathrm{a}}$

\begin{tabular}{|c|c|c|c|}
\hline \multirow{2}{*}{$\begin{array}{l}\text { Conc } \\
\mathrm{mM} \\
\end{array}$} & \multicolumn{3}{|c|}{ Seed germination $\% \pm \mathbf{S E}^{\mathbf{b}}$} \\
\hline & 1 & 2 & 3 \\
\hline 0 & $70.0 \pm 0.0 \mathrm{a}$ & $70.0 \pm 0.0 \mathrm{a}$ & $70.0 \pm 0.0 \mathrm{a}$ \\
\hline 0.5 & $41.7 \pm 1.66 b$ & $60.0 \pm 2.89 \mathrm{~b}$ & $41.7 \pm 4.44 b$ \\
\hline 1 & $48.3 \pm 6.05 b$ & $41.7 \pm 1.66 \mathrm{c}$ & $51.7 \pm 7.31 \mathrm{~b}$ \\
\hline 5 & $13.3 \pm 1.66 \mathrm{c}$ & $30.0 \pm 2.89 \mathrm{~d}$ & $36.7 \pm 6.01 \mathrm{~b}$ \\
\hline Conc & \multicolumn{3}{|c|}{ Seed germination $\% \pm \mathrm{SE}$} \\
\hline $\mathrm{mM}$ & 4 & 5 & 6 \\
\hline 0 & $70.0 \pm 0.0 \mathrm{a}$ & $70.0 \pm 0.0 \mathrm{a}$ & $70.0 \pm 0.0 \mathrm{a}$ \\
\hline 0.5 & $58.3 \pm 6.01 b$ & $61.7 \pm 4.41 b$ & $53.3 \pm 1.67 b$ \\
\hline 1 & $45.0 \pm 2.89 \mathrm{c}$ & $51.7 \pm 3.34 b c$ & $38.3 \pm 4.41 \mathrm{c}$ \\
\hline 5 & $0.0 \pm 0.0 \mathrm{~d}$ & $25.0 \pm 5.01 \mathrm{c}$ & $20.0 \pm 2.89 \mathrm{~d}$ \\
\hline Conc & \multicolumn{3}{|c|}{ Seed germination $\% \pm \mathrm{SE}$} \\
\hline $\mathrm{mM}$ & 7 & 8 & 9 \\
\hline 0 & $70.0 \pm 0.0 \mathrm{a}$ & $70.0 \pm 0.0 \mathrm{a}$ & $70.0 \pm 0.0 \mathrm{a}$ \\
\hline 0.5 & $31.7 \pm 4.41 b$ & $56.7 \pm 4.41 b$ & $65.0 \pm 5.78 \mathrm{a}$ \\
\hline 1 & $28.3 \pm 1.66 b$ & $55.0 \pm 2.89 \mathrm{~b}$ & $53.3 \pm 4.41 \mathrm{a}$ \\
\hline 5 & $0.0 \pm 0.0 \mathrm{c}$ & $18.3 \pm 1.67 \mathrm{c}$ & $31.7 \pm 4.41 \mathrm{~b}$ \\
\hline
\end{tabular}

${ }^{a}$ Data are expressed as means \pm SE from experiments with three replicates of 20 seeds each.

${ }^{\mathrm{b}}$ Mean values within a column sharing the same letter are not significantly different at the 0.05 probability level. 


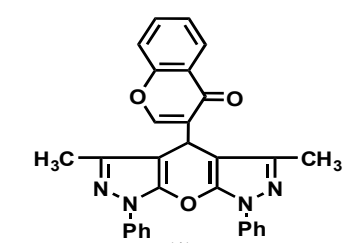

(1)

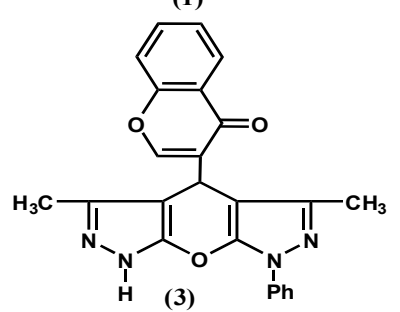

(3)

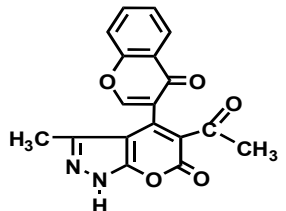

(5)

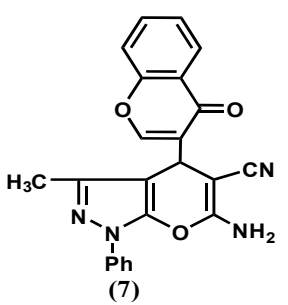

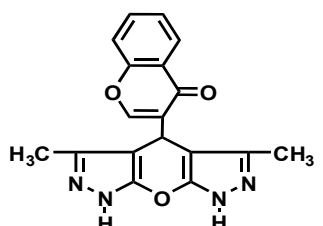

(2)<smiles>Cc1n[nH]c2oc(=O)c(C#N)c(-c3coc4ccccc4c3=O)c12</smiles>

(4)

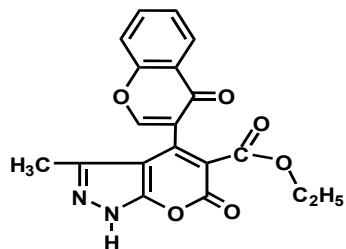

(6)

Figure 1. The chemical structures of pyranopyrazoles and oxinobispyrazoles(1-9)

\section{Effect of pyranopyrazoles and oxinobispyrazoles on root growth}

The results showed that the tested compounds exhibited significant reduction of root growth of $L$. temulentum at all tested concentrations compared to control, except for compound 4 at the lowest concentration $(0.5 \mathrm{mM})$ and compound 1 at concentrations 0.5 and $1 \mathrm{mM}$ (Table 2).

Compound 3 caused the highest root growth reduction at $0.5 \mathrm{mM}$ with $57 \%$ growth inhibition. Similarly, compounds 6, 5, 8 and 7 displayed strong root growth reduction at this concentration with 50.4, $49.8,46.5$ and $46.3 \%$ growth reduction, respectively. In contrast, compound 4 revealed the lowest reduction of root growth at this concentration. At $1 \mathrm{mM}$, compound 7 was the most potent root growth inhibitor, followed by compounds 8 and 4 with 76.2, 71.7 and $67.7 \%$ growth reduction, respectively. Compound 1 had the weakest effect on root growth. Compounds 4 and 7 caused complete root growth inhibition at $5 \mathrm{mM}$. Likewise, compounds 8, 9, 6 and 5 displayed strong effect on root growth (reduction $>90 \%$ ). In contrary, compound 1 revealed the weakest effect of root growth at this concentration.

\section{Effect of pyranopyrazoles and oxinobispyrazoles on shoot growth}

The results demonstrate that the pyranopyrazoles and oxinobispyrazoles had pronounced effect on shoot growth of $L$. temulentum. The tested compounds (1-9) caused significant reduction of shoot growth at the tested concentrations, except compound 1 at 0.5 and 1 $\mathrm{mM}$, and compound 2 at $0.5 \mathrm{mM}$ (Table 3). Compound 7 (growth inhibition $=44.5 \%$ ) was the most active at $0.5 \mathrm{mM}$, followed by compound 8 (growth inhibition $=$ $31.8 \%$ ), while compound 1 (growth inhibition $=5.2 \%$ ) was the less effective one among the tested compounds. In addition, compounds 7, 6 and 4 caused the highest shoot growth reduction at $1 \mathrm{mM}$. In contrary, compounds 1 and 3 had the lowest growth reduction at this concentration. At $5 \mathrm{mM}$, compounds 4 and 7 caused complete inhibition of shoot growth. Compounds 8, 6 and 2 showed strong reduction of shoot growth, while compound 3 was the less effective one at $5 \mathrm{mM}$.

The results of the present study indicated that compounds (1-9) had herbicidal activity against $L$. 
temulentum. These results are supported by the study of Badawy et al. (2016) who mentioned that the tested compounds caused reduction on seed germination and seedling growth of Portulaca oleracea.

Despite the lack of reported studies on herbicidal activity of the tested pyranopyrazoles and oxinobispyrazoles, some pyrazoles were described to possess herbicidal activity. For example, Ma et al. (2010) synthesized a series of novel $N$-(2,2,2)trifluoroethylpyrazole derivatives and evaluated their herbicidal activity against dicotyledonous and monocotyledonous weeds.

Table 2. Effect of pyranopyrazoles and oxinobispyrazoles on Lolium temulentum root growth 12 days after sowing ${ }^{\mathrm{a}}$

\begin{tabular}{|c|c|c|c|c|c|c|}
\hline \multirow{2}{*}{$\begin{array}{l}\text { Conc } \\
\mathbf{m M} \\
\end{array}$} & \multicolumn{2}{|l|}{1} & \multicolumn{2}{|l|}{2} & \multicolumn{2}{|l|}{3} \\
\hline & Root length (cm) & $\mathbf{R}(\%)^{b}$ & Root length (cm) & R (\%) & Root length (cm) & R (\%) \\
\hline 0 & $5.12 \pm 0.26 \mathrm{a}$ & 0.0 & $5.12 \pm 0.26 \mathrm{a}$ & 0.0 & $5.12 \pm 0.26 \mathrm{a}$ & 0.0 \\
\hline 0.5 & $3.91 \pm 0.31 \mathrm{a}$ & 23.6 & $3.0 \pm 0.19 b$ & 41.4 & $2.18 \pm 0.29 b$ & 57.4 \\
\hline 1 & $3.87 \pm 0.43 \mathrm{a}$ & 24.4 & $2.83 \pm 0.17 b$ & 44.7 & $2.75 \pm 0.25 b$ & 46.3 \\
\hline 5 & $2.43 \pm 0.28 \mathrm{~b}$ & 52.5 & $0.71 \pm 0.39 \mathrm{c}$ & 86.1 & $1.24 \pm 0.26 \mathrm{c}$ & 75.8 \\
\hline \multirow{2}{*}{$\begin{array}{l}\text { Conc } \\
\mathbf{m M} \\
\end{array}$} & \multicolumn{2}{|l|}{4} & \multicolumn{2}{|l|}{5} & \multicolumn{2}{|l|}{6} \\
\hline & Root length (cm) & $\mathbf{R}(\%)$ & Root length (cm) & $\mathbf{R}(\%)$ & Root length (cm) & $\mathrm{R}(\%)$ \\
\hline 0 & $5.12 \pm 0.26 \mathrm{a}$ & 0.0 & $5.12 \pm 0.26 \mathrm{a}$ & 0.0 & $5.12 \pm 0.26 \mathrm{a}$ & 0.0 \\
\hline 0.5 & $4.63 \pm 0.35 \mathrm{a}$ & 9.6 & $2.57 \pm 0.22 b$ & 49.8 & $2.54 \pm 0.23 b$ & 50.4 \\
\hline 1 & $1.65 \pm 0.34 b$ & 67.7 & $1.77 \pm 0.26 \mathrm{c}$ & 65.4 & $1.75 \pm 0.39 b$ & 65.8 \\
\hline 5 & $0.0 \pm 0.0 \mathrm{c}$ & 100.0 & $0.5 \pm 0.0 \mathrm{~d}$ & 90.2 & $0.3 \pm 0.12 \mathrm{c}$ & 94.1 \\
\hline \multirow{2}{*}{$\begin{array}{l}\text { Conc } \\
\mathbf{m M}\end{array}$} & \multicolumn{2}{|l|}{7} & \multicolumn{2}{|l|}{8} & \multicolumn{2}{|l|}{9} \\
\hline & Root length (cm) & R (\%) & Root length (cm) & $\mathbf{R}(\%)$ & Root length (cm) & $\mathbf{R}(\%)$ \\
\hline 0 & $5.12 \pm 0.26 \mathrm{a}$ & 0.0 & $5.12 \pm 0.26 \mathrm{a}$ & 0.0 & $5.12 \pm 0.26 \mathrm{a}$ & 0.0 \\
\hline 0.5 & $2.37 \pm 0.12 b$ & 46.3 & $2.74 \pm 0.26 b$ & 46.5 & $3.20 \pm 0.14 b$ & 37.5 \\
\hline 1 & $1.22 \pm 0.22 \mathrm{c}$ & 76.2 & $1.45 \pm 0.19 \mathrm{c}$ & 71.7 & $1.98 \pm 0.16 \mathrm{c}$ & 61.3 \\
\hline 5 & $0.0 \pm 0.0 \mathrm{~d}$ & 100.0 & $0.13 \pm 0.09 \mathrm{~d}$ & 97.5 & $1.03 \pm 0.07 \mathrm{~d}$ & 79.9 \\
\hline
\end{tabular}

${ }^{a}$ Data are expressed as means \pm SE from experiments with three replicates of 20 seeds each.

${ }^{\mathrm{b}} \mathrm{I}=$ reduction.

${ }^{\mathrm{c}}$ Mean values within a column sharing the same letter are not significantly different at the 0.05 probability level.

Table 3. Effect of pyranopyrazoles and oxinobispyrazoles on Lolium temulentum shoot growth 12 days after sowing ${ }^{\mathrm{a}}$

\begin{tabular}{|c|c|c|c|c|c|c|}
\hline \multirow{2}{*}{$\begin{array}{l}\text { Conc } \\
\mathrm{mM}\end{array}$} & \multicolumn{2}{|l|}{1} & \multicolumn{2}{|l|}{2} & \multicolumn{2}{|l|}{3} \\
\hline & Shoot length $(\mathrm{cm})$ & $\mathbf{R}(\%)^{\mathbf{b}}$ & Shoot length $(\mathrm{cm})$ & R (\%) & Shoot length $(\mathrm{cm})$ & $\mathbf{R}(\%)$ \\
\hline 0 & $7.82 \pm 0.24 \mathrm{a}$ & 0.0 & $7.82 \pm 0.24 \mathrm{a}$ & 0.0 & $7.82 \pm 0.24 \mathrm{a}$ & 0.0 \\
\hline 0.5 & $7.41 \pm 0.26 \mathrm{a}$ & 5.2 & $6.88 \pm 0.26 \mathrm{ab}$ & 12.0 & $6.09 \pm 0.24 b$ & 22.1 \\
\hline 1 & $7.22 \pm 0.54 \mathrm{a}$ & 7.7 & $6.18 \pm 0.59 b$ & 21.0 & $6.74 \pm 0.32 b$ & 13.8 \\
\hline 5 & $3.70 \pm 0.32 b$ & 52.7 & $2.83 \pm 0.09 \mathrm{c}$ & 63.8 & $4.48 \pm 0.52 c$ & 42.7 \\
\hline \multirow{2}{*}{$\begin{array}{l}\text { Conc } \\
\text { mM }\end{array}$} & \multicolumn{2}{|l|}{4} & \multicolumn{2}{|l|}{5} & \multicolumn{2}{|l|}{6} \\
\hline & Shoot length (cm) & R (\%) & Shoot length $(\mathrm{cm})$ & R (\%) & Shoot length $(\mathrm{cm})$ & R (\%) \\
\hline 0 & $7.82 \pm 0.24 \mathrm{a}$ & 0.0 & $7.82 \pm 0.24 \mathrm{a}$ & 0.0 & $7.82 \pm 0.24 \mathrm{a}$ & 0.0 \\
\hline 0.5 & $6.0 \pm 0.50 \mathrm{~b}$ & 23.3 & $6.29 \pm 0.27 b$ & 19.6 & $6.11 \pm 0.20 b$ & 21.9 \\
\hline 1 & $4.38 \pm 0.25 c$ & 44.0 & $6.21 \pm 0.41 b$ & 20.6 & $4.26 \pm 0.50 c$ & 45.5 \\
\hline 5 & $0.0 \pm 0.0 \mathrm{~d}$ & 100.0 & $3.56 \pm 0.18 \mathrm{c}$ & 54.5 & $2.31 \pm 0.36 \mathrm{~d}$ & 70.5 \\
\hline \multirow{2}{*}{$\begin{array}{l}\text { Conc } \\
\mathrm{mM}\end{array}$} & \multicolumn{2}{|l|}{7} & \multicolumn{2}{|l|}{8} & \multicolumn{2}{|l|}{9} \\
\hline & Shoot length (cm) & R (\%) & Shoot length (cm) & R (\%) & Shoot length $(\mathrm{cm})$ & R (\%) \\
\hline 0 & $7.82 \pm 0.24 \mathrm{a}$ & 0.0 & $7.82 \pm 0.24 \mathrm{a}$ & 0.0 & $7.82 \pm 0.24 \mathrm{a}$ & 0.0 \\
\hline 0.5 & $4.34 \pm 0.33 b$ & 44.5 & $5.33 \pm 0.33 b$ & 31.8 & $6.32 \pm 0.24 b$ & 19.2 \\
\hline 1 & $3.48 \pm 0.25 \mathrm{c}$ & 55.5 & $4.81 \pm 0.23 b$ & 38.5 & $5.03 \pm 0.29 c$ & 35.7 \\
\hline 5 & $0.0 \pm 0.0 \mathrm{~d}$ & 100.0 & $0.91 \pm 0.50 \mathrm{c}$ & 88.4 & $3.35 \pm 0.16 \mathrm{~d}$ & 57.2 \\
\hline
\end{tabular}

${ }^{a}$ Data are expressed as means \pm SE from experiments with three replicates of 20 seeds each.

${ }^{\mathrm{b}} \mathrm{R}=$ reduction.

${ }^{\mathrm{c}}$ Mean values within a column sharing the same letter are not significantly different at the 0.05 probability level 
Some of the tested compounds exhibited better herbicidal activity by soil application than the commercial herbicide, metolachlor. Kang et al. (2015) stated that pyrazoles exhibited excellent herbicidal activities at the concentration of $100 \mathrm{mg} / \mathrm{L}$, and compound 5-chloro-2-((3-methyl-1-(2,2,2trifluoroethyl)-1H-pyrazol-5-yl)oxy)pyrimidine showed bleaching activity to green weeds. In addition, pyrazole derivatives were described to have herbicidal activities against Brassica napus, Echinochloa crusgalli, E. oryzicola, Lindernia procumbens, Eleocharis acicularis, Sagittaria pygmaea, Cyperus serotinus, $C$. difformis, Eleocharis acicularis, E. kuroguwai, Monochoria vaginalis, Rotala indica, Elatine triandra, Ammannia multiflora and Scirpus juncoides (Kudo et al., 1999; Ohno et al., 2004; Xu et al., 2012).

The results indicated that the tested pyranopyrazoles and oxinobispyrazoles exhibited greater inhibitory effects on seedling growth than on seed germination. A similar finding was described by Leather and Einhellig (1985) who demonstrated that bioassays determining seedling growth of many allelochemicals are usually more sensitive than those measuring germination. In addition, all of the tested compounds had greater inhibitory effects on root growth than on shoot growth. These results are supported by our earlier studies of inhibitory effects of essential oils, sesquiterpenes and monoterpenes on seedling growth (Abdelgaleil et al., 2009 and 2014; Saad et al., 2012; Gouda et al., 2016). This finding might be predictable, because it is likely that roots are the first to absorb the allelochemicals compounds from the media (Turk and Tawaha 2002).

4. Insecticidal activity of pyranopyrazoles and oxinobispyrazoles on Culex pipiens fourth instar larvae

Pyranopyrazoles and oxinobispyrazoles (1-9) were tested for their toxicity against the fourth instar larvae of $C$. pipiens. In general, all of the tested compounds showed insecticidal activity. However the toxicity was compound, concentration and time dependent. After 24 $\mathrm{h}$ of treatment at $125 \mathrm{mg} / \mathrm{L}$, compound 7 exhibited the highest larval mortality, followed by compounds 4 and 8 (Table 4). Similarly, compounds 7 and 8 showed the highest toxicity at this concertation after $48 \mathrm{~h}$ of treatment, while compound 2 had the least toxicity. The tested compounds caused higher larval toxicity at 250 $\mathrm{mg} / \mathrm{L}$ with compound 7 being the most potent after 24 $\mathrm{h}$, followed by compounds 4 and 8 . After $48 \mathrm{~h}$ of treatment, compound 7 caused complete larval mortality and compounds 1, 4 and 8 showed strong insecticidal activity. All of the tested compounds revealed potent toxicity against $C$. pipiens larvae at $500 \mathrm{mg} / \mathrm{L}$ after $24 \mathrm{~h}$ except compounds 2 and 9 . After 48 h, compounds 1 and 7 caused complete larval mortality. In addition, compounds 4, 5 and 8 displayed strong insecticidal activity, while compound 2 was the less effective one at this concentration.

To the best of our knowledge there were no reported studies on the insecticidal activity of synthetized pyranopyrazoles and oxinobispyrazoles (1-9) against $C$. pipiens or other insects. Nevertheless, many pyrazoles have been stated to have insecticidal activity against different insect species. Song et al. (2012) evaluated the insecticidal or acaricidal activity some pyrazoles containing 4,5-dihydrooxazole moieties against Helicoverpa armigera, Plutella xylostella, Aphis craccivora, Culex pipiens pallens and Tetranychus cinnabarinus. Some of the prepared compounds showed high insecticidal activity against the tested insects and spider mite. In addition, pyrazole derivatives exhibited notable control of $P$. xylostella, $H$. armigera, $C$. pipiens pallens, Laphygma exigua, Spodoptera litura, Nilaparvata lugens and Rhopalosiphum maidis $(\mathrm{Wu}$ et al. 2012).

Table 4. Mortality percentages of Culex pipiens fourth instar larvae after 24 and $48 \mathrm{~h}$ of treatment with pyranopyrazoles and oxinobispyrazoles at different concentrations

\begin{tabular}{|c|c|c|c|c|c|c|}
\hline \multirow[t]{3}{*}{ Compound } & \multicolumn{6}{|c|}{ Mortality (\%) $\pm \mathrm{SE}^{\mathrm{a}}$} \\
\hline & \multicolumn{2}{|c|}{$125 \mathrm{mg} / \mathrm{L}$} & \multicolumn{2}{|c|}{$250 \mathrm{mg} / \mathrm{L}$} & \multicolumn{2}{|c|}{$500 \mathrm{mg} / \mathrm{L}$} \\
\hline & $24 \mathrm{~h}$ & $48 \mathrm{~h}$ & $24 \mathrm{~h}$ & $48 \mathrm{~h}$ & $24 \mathrm{~h}$ & $48 \mathrm{~h}$ \\
\hline 1 & $20.0 \pm 0.0 \mathrm{c}$ & $53.3 \pm 6.67 b$ & $26.7 \pm 6.67 \mathrm{c}$ & $80.0 \pm 5.78 b$ & $80.0 \pm 5.78 b$ & $100.0 \pm 0.0 \mathrm{a}$ \\
\hline 2 & $0.0 \pm 0.0 \mathrm{~d}$ & $6.7 \pm 6.67 \mathrm{~cd}$ & $0.0 \pm 0.0 \mathrm{~d}$ & $53.3 \pm 6.67 \mathrm{c}$ & $13.3 \pm 6.67 \mathrm{~d}$ & $53.3 \pm 6.7 \mathrm{c}$ \\
\hline 4 & $36.7 \pm 3.34 \mathrm{~b}$ & $40.0 \pm 0.0 \mathrm{~b}$ & $43.3 \pm 3.34 b$ & $73.3 \pm 3.34 b$ & $66.7 \pm 3.34 b$ & $86.7 \pm 3.34 \mathrm{a}$ \\
\hline 5 & $10.0 \pm 0.0 \mathrm{~d}$ & $50.0 \pm 0.0 \mathrm{~b}$ & $10.0 \pm 0.0 \mathrm{~d}$ & $50.0 \pm 0.0 \mathrm{c}$ & $70.0 \pm 5.78 b$ & $96.7 \pm 3.34 \mathrm{a}$ \\
\hline 7 & $63.3 \pm 3.34 \mathrm{a}$ & $80.0 \pm 5.78 \mathrm{a}$ & $76.7 \pm 3.34 \mathrm{a}$ & $100.0 \pm 0.0 \mathrm{a}$ & $100.0 \pm 0.0 \mathrm{a}$ & $100.0 \pm 0.0 \mathrm{a}$ \\
\hline 8 & $30.0 \pm 5.78 b$ & $73.3 \pm 6.67 \mathrm{a}$ & $36.7 \pm 3.34 b$ & $80.0 \pm 5.78 b$ & $66.7 \pm 8.83 b$ & $90.0 \pm 5.78 \mathrm{a}$ \\
\hline 9 & $0.0 \pm 0.0 \mathrm{~d}$ & $20.0 \pm 0.0 \mathrm{c}$ & $20.0 \pm 0.0 \mathrm{c}$ & $46.7 \pm 6.67 \mathrm{c}$ & $33.3 \pm 3.34 \mathrm{c}$ & $66.7 \pm 6.67 b$ \\
\hline Control & $0.0 \pm 0.0 \mathrm{~d}$ & $0.0 \pm 0.0 \mathrm{~d}$ & $0.0 \pm 0.0 \mathrm{~d}$ & $0.0 \pm 0.0 \mathrm{~d}$ & $0.0 \pm 0.0 \mathrm{~d}$ & $0.0 \pm 0.0 \mathrm{~d}$ \\
\hline
\end{tabular}

${ }^{a}$ Means within each column followed by the same letter are not significantly different $(\mathrm{P}=0.05)$. 
Moreover, the insecticidal or acaricidal activities of pyrazole derivatives against Nephotettix cincticeps, Tetranychus urtica and Periplaneta americana have been described (Verma and Nayal, 2003; Ohno et al., 2010).

The structure-herbicidal activity relationship examination of the tested compounds revealed that the compounds containing two pyrazole rings or oxinobispyrazoles such as 1,2 and 3 were less active than compounds containing one pyrazole ring or pyranopyrazoles (4-9) against $L$. temulentum. Among the bi-pyrazole (1-3), compound 1 which bearing no phenyl moiety was more active than compound 2 which bearing one phenyl moiety at $\mathrm{N}-1$ and both compounds were more active than 3 which bearing two phenyl moieties at $\mathrm{N}-1$ and $\mathrm{N}-1^{\prime}$. The presence of cyanide $(\mathrm{CN})$ group at $\mathrm{C}-5$ increased the herbicidal activity of compound 4 comparing with 5 and 6 . Compounds 4 and 8 revealed similar herbicidal activity against $L$. temulentum, indicating that the substitution of $\mathrm{H}$ by phenyl at N-1 had no significant effect on the herbicidal activity. However, the presence of phenyl at N-1 strongly enhanced the activity of compound 7 comparing with compound 9.

On the other hand, the presence of two phenyl moieties on $\mathrm{N}-1$ and $\mathrm{N}-1{ }^{\prime}$ in compound 1 increased the toxicity of compound 1 to $C$. pipiens larvae comparing with 2 which bearing no phenyl. Comparing the toxicity of compounds 4 and 5 indicated that the substitution at C-5 either by $\mathrm{CN}$ or $\mathrm{COCH}_{3}$ had no notable effect on the toxicity. Moreover, the presence of phenyl ring at $\mathrm{N}-1$ in compound 7 increased the toxicity of the compound compared with compound 9.

In summary, nine pyranopyrazoles and oxinobispyrazoles (1-9) were prepared and tested for their herbicidal activity against $L$. temulentum and their insecticidal activity against $C$. pipiens. Among the tested compounds, 4, 6, 7, and 8 showed promising herbicidal activity against $L$. temulentum. In addition, compounds $1,5,7$ and 8 displayed the highest insecticidal activity against $C$. pipiens larvae. These compounds seem promising and warrant further studies in the future.

\section{ACKNOWLEDGMENT}

The authors are grateful to Tarek A. Abdo, Abdelhameed A. Abdelhameed, Fatma M. Habiba, Yomna Y. Seddik, Hadeer M. Menesy and Abdelrahman M. Attia for their efforts during the experimental section of this work.

\section{REFERENCES}

Abd El-Samie, E. and T., Abd El-Baset. 2012. Efficacy of some insecticides on field populations of Culex pipiens (Linnaeus) from Egypt. J. Basic. Appl. Zool. 65:62-73.

Abdelgaleil, S.A.M., N. Abdel-Razeek and S. A. Soliman. 2009. Herbicidal activity of three sesquiterpene lactones on wild oat (Avena fatua) and their possible mode of action. Weed Sci. 57:6-9.

Abdelgaleil, S.A.M., M.M.G. Saad and B. Y. Hassan. 2014. Chemical composition and inhibitory effects of essential oils on germination and seedling growth of barnyard grass (Echinochloa crusgalli L.). Alex. Sci. Exch. J. 35:278287.

Abdelrazek, F.M., F.A. Michael and A.E. Mohamed. 2006. Synthesis and molluscicidal activity of some 1,3,4-triaryl5-chloropyrazole, pyrano[2,3-c]pyrazole, pyrazolylphthalazine and pyrano[2,3-d]thiazole derivatives. Arch. Pharm. Chem. Life Sci. 339:305-312.

Abdelrazek, F.M., P. Metz1, O. Kataeva1, A. Jäger and S. F. El-Mahrouky. 2007. Synthesis and molluscicidal activity of new chromene and pyrano[2,3-c]pyrazole derivatives. Arch. Pharm. Chem. Life Sci. 340:543-548.

Ahluwalia, V.K., A. Dahiya and V. Garg. 1997. Reaction of 5amino-4-formyl-3-methyl(or phenyl)-1-phenyl- $1 \mathrm{H}$ pyrazoles with active methylene compounds: Synthesis of fused heterocyclic rings. Indian J. Chem. 36B:88-90.

Ambasta, S.P. 1994. The Useful Plants of India. New Delhi, India: Publication and Information Directorate CSIR

Badawy Y.M., A.F. El-Sayed, F.S. Soliman and M.S. MohyAldin. 2016. Synthesis of some new annulated pyranopyrazole derivatives, a new series of herbicidal substances and some related compounds. Int. J. Engin. Sci. Innov. Technol. 5:33-39.

Bor, N.L., 1960. The Grasses of Burma, Ceylon, India and Pakistan (Excluding Bambusae). Oxford, UK: Pergamon Press.

Cheng, S.-S., C.-G. Huang, W.-J. Chen, Y.-H. Kuo and S.-T., Chang. 2008. Larvicidal activity of tectoquinone isolated from red heartwood-type Cryptomeria japonica against two mosquito species. Bioresour. Technol. 99:36173622 .

Cohort Software Inc. 1985. Costat User's Manual. Version 3. Tucson, AZ: Cohort.

Dannhardt, G. and L. Steindl. 1985. Alkaloids of Lolium temulentum: isolation, identification and pharmacological activity. Planta Medica 3:212-214.

Farnworth, J. and S. A. Said. 1983. The effect of nitrogen and irrigation frequency on Red River wheat (spring 1982). Publication No. 61. Dhamar, Yemen: Dhamar Agricultural Improvement Centre. 
Gouda, N.A.A., M.M.G. Saad and S.A.M. Abdelgaleil. 2016. Pre- and Post-emergent herbicidal activity of monoterpenes against barnyard grass, Echinochloa crusgalli. Weed Sci. 64:191-200.

Hollies, J. D. 1982. A survey of commercially grown high yielding wheat and barley crops from 1977 to 1981. Proceedings, British Crop Protection Conference - Weeds, 609-618.

Holm, L.G., J.V. Pancho, J. P. Herberger and D.L. Plucknett. 1991. A geographic atlas of world weeds. Malabar, Florida, USA: Krieger Publishing Company.

Kang J., X.L. Yue, C.S. Chen, J.H. Li and H.J. Ma. 2015. Synthesis and herbicidal activity of 5-heterocycloxy-3methyl-1-substituted-1H-pyrazoles. Molecules 21:39-51.

Khurana, J.M. and A. Chaudhary. 2012. Efficient and green synthesis of 4H-pyrans and 4H-pyrano[2,3-c] pyrazoles catalyzed by task-specific ionic liquid [bmim]OH under solvent-free conditions, Green Chem. Lett. Rev. 5:4:633638 .

Kudo, N., S. Furuta, M. Taniguchi, T. Endo, and K. Sato. 1999. Synthesis and herbicidal activity of 1, 5-diaryl pyrazole derivatives. Chem. Pharm. Bull. 47:857-868.

Kuo, S.C., L.J. Huang and H. Nakamura.1984. Studies on heterocyclic compounds. 6. Synthesis and analgesic and antiinflammatory activities of 3,4-dimethyl-pyra- 2,3c]pyrazol-6-one derivatives. J. Med. Chem. 27:539-544.

Leather, G.R. and F.A. Einhellig.1985. Mechanisms of Allelopathic action in bioassay. Pages 197-205 in The Chemistry of Allelopathy. Washington, DC: American Chemical Society.

Ma, H.-J., Y.-H. Li, Q.-F. Zhao, T. Zhang, R.-L. Xie, X.-D. Mei and J. Ning. 2010. Synthesis and herbicidal activity of novel $N$-(2,2,2)-trifluoroethylpyrazole derivatives. J. Agric. Food Chem. 58:4356-4360.

Mangalagiu, G., M. Ungureanu, G. Grosu, I. Mangalagiu and M. Petrovanu. 2001. New pyrrolo-pyrimidine derivatives with antifungal or antibacterial properties, Ann. Pharm. Fr. 59:139-140.

Mistry, P.T., N.R. Kamdar, D.D. Haveliwala and S.K. Patel. 2012. Synthesis, characterization, and in vitro biological studies of some novel pyran fused pyrimidone derivatives. J. Heterocyclic Chem. 49:349-357.

Ohno, R., A. Watanabe, T. Matsukawa, T. Ueda, H. Sakurai, M. Hori and K. Hirai. 2004. Synthesis and herbicidal activity of new pyrazole-4-carboxamide derivatives. J. Pest. Sci. 29:15-26.

Ohno, R., M. Nagaoka, K. Hirai, A. Uchida, S. Kochi, O. Yamada and J. Tokumura. 2010. Synthesis and insecticidal activity of novel 1-alkyl-3sulfonyloxypyrazole-4-carboxamide derivatives. J. Pestic. Sci. 35:15-22.
Ratera, E.L. 1983. Bibliographic guide to plants toxic to stock in the Argentine Republic. (Second contribution: grasses). Revista de Ciencias Agrarias, Universidad Catolica Argentina, 4(1/2):38-42, 44-48, 50-52.

Saad, M.M.G., S.A.M. Abdelgaleil and T. Suganuma. 2012. Herbicidal potential of pseudoguaninolide sesquiterpenes on wild oat, Avena fatua L. Biochem. Syst. Ecol. 44: 333337.

Satyajit, S., C. Anuja, S. Gurpinder, K.S. Ajit, and P.S.I. Mohan. 2013. Synthesis and in-vitro cytotoxic evaluation of novel chromano-piperidine fused isoxazolidines: Discovery of a potent lead. J. Pharm. Res. 7:337-341.

Smith, A. and Bernhard. 1988. Poisonous plants of all countries. New Delhi, India: Soni Reprints Agency.

Song, H., Y. Liu, L. Xiong, Y. Li, N. Yang and Q. Wang. 2012. Design, synthesis, and insecticidal activity of novel pyrazole derivatives containing $\alpha$-hydroxymethyl-Nbenzyl carboxamide, $\alpha$-chloromethyl-N-benzyl carboxamide, and 4,5-dihydrooxazole moieties. J. Agric. Food Chem. 60:1470-1409.

Turk, M.A. and A.M.Tawaha. 2002. Inhibitory effects of aqueous extracts of black mustard on germination and growth of lentil. Pak. J. Agron. 1:28-30.

Verma, R.K. and S.S. Nayal. 2003. Study of insecticidal activity of some pyrazoles derivatives against American cockroaches. Indian J. Chem Tech.10:347-349.

Wang, J.L., D. Liu, Z. J. Zheng, S. Shan, X. Han, S. M. Srinivasula, C. M. Croce, E. S. Alnemri and Z. Huang. 2009. Structure-based discovery of an organic compound that bind $\mathrm{Bc} 1-2$ protein and induces apoptosis of tumor cells. Proc. Natl. Acad. Sci. U.S.A., 97:124-7129.

WHO, 1996. Report of the WHO informal consultation on the evaluation on the testing of insecticides CTD/WHO PES/IC/96.1, p69.

Wu. J., B.A. Song, D.Y. Hu, M. Yue and S. Yang. 2012. Design, synthesis and insecticidal activities of novel pyrazole amides containing hydrazone substructures. Pest Manag Sci. 68:801-810.

Xu, H., X.-H. Hu, X.-M. Zou, Y.-Q. Zhu, B. Liu, F.-Z. Hu and H.-Z. Yang. 2012. Synthesis and herbicidal activity of 5heterocycloxy-3- substituted-1-(3-trifluoromethyl)phenyl$1 H$-pyrazole. Chem. Res. Chinese Universities 28:824827.

Zaki, M.E.A., H.A. Saliman, O.A. Hiekal and A.E. Rashad. 2006. Pyrazolopyranopyrimidines as a class of antiInflammatory agents. Z. Naturforsch., C: Biosci. 61:1-5.

Zaki, M.E.A., E.M. Morsy, F.M. Abdel-Motti and F.M.E. Abdel-Megeid. 2004. The Behaviour of Ethyl 1-acetyl-4aryl-5-cyano-3-methyI-1,4-dihydropyrano[2,3-c]pyrazol6-ylimidoformate Towards Nucleophiles. Heterocycl. Commun. 10:97-102. 


\section{الملذص العري \\ رلسلت عل النشلا الإبادى ضد الهشائش والهشرات والملفة بين التركيب الكيميائي والنشلا لمركبلت

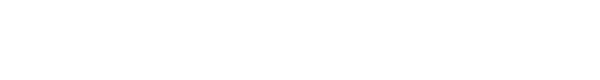

سمير عبد الظيم عبد الجلل، يونس محمود بدوى

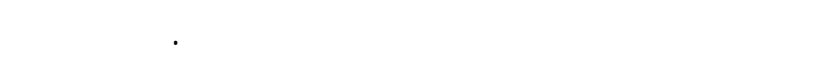

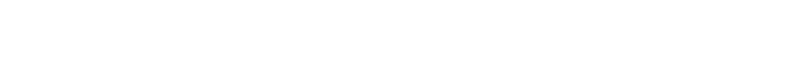

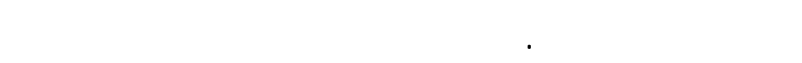

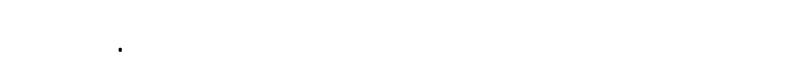

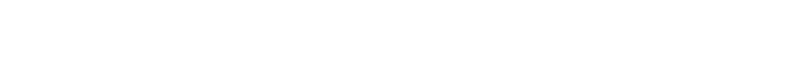

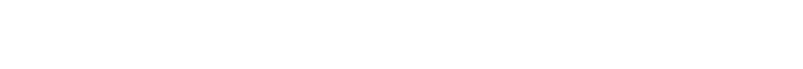

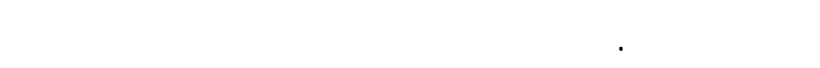

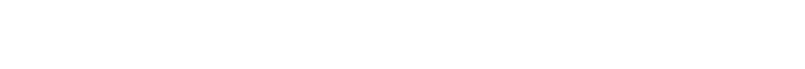

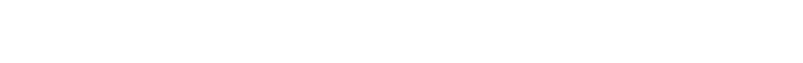

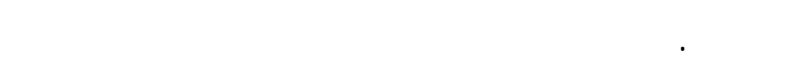

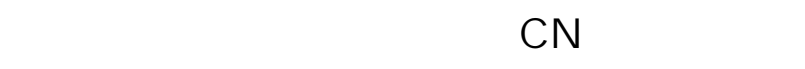

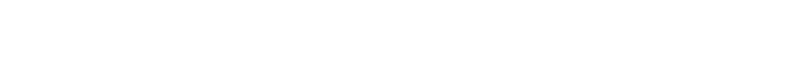

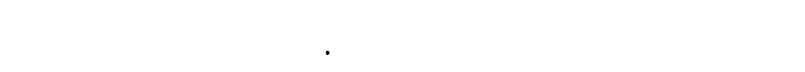

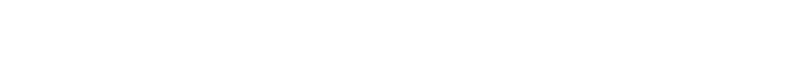

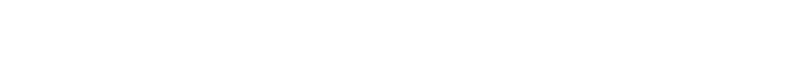

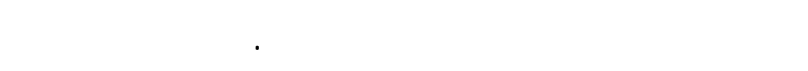

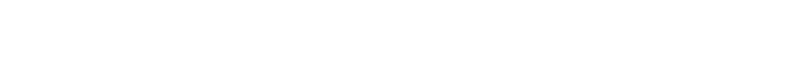
منلسبة لظوير بعض المبيدات الجدية.

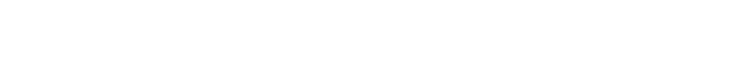

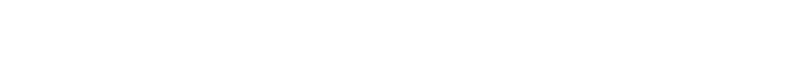
التركيب الكيميائع بولططةط ورق التحليل الطيفى المختلف ـة.

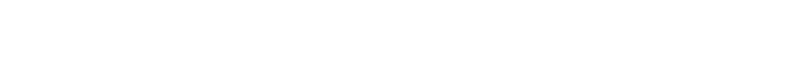

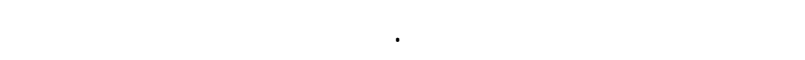

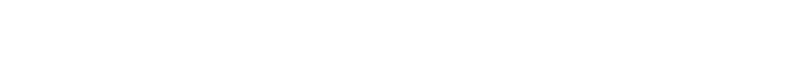

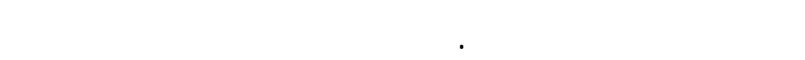

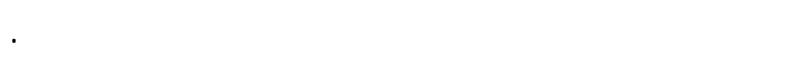

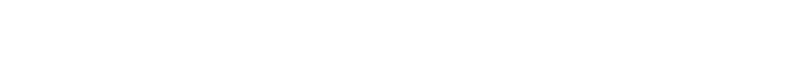

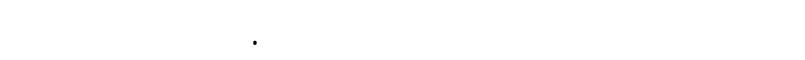

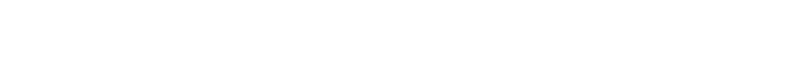

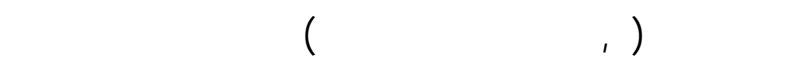

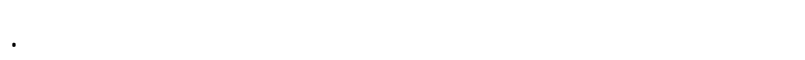

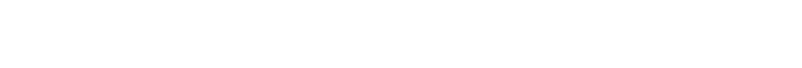

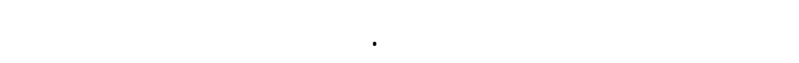

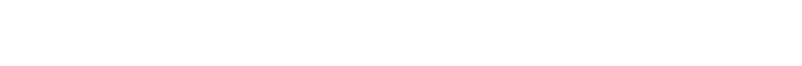

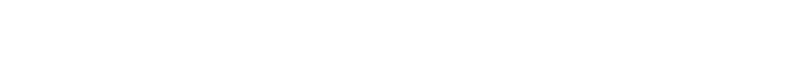

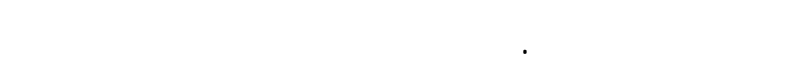

